\title{
Small Intestinal Lipoma
}

National Cancer Institute

\section{Source}

National Cancer Institute. Small Intestinal Lipoma. NCI Thesaurus. Code C5339.

A rare benign adipose tissue neoplasm of the small intestine. It usually arises from the submucosa and occasionally protrudes into the lumen. 